\title{
An extremely compensatible cigarette by design: documentary evidence on industry awareness and reactions to the Barclay filter design cheating the tar testing system
}

\author{
L T Kozlowski, N A Dreschel, S D Stellman, J Wilkenfeld, E B Weiss, M E Goldberg
}

Tobacco Control 2005;14:64-70. doi: 10.1136/tc.2004.009167

See end of article for authors' affiliations

\section{Correspondence to: Lynn T Kozlowski, PhD, Department of Biobehavioral Health, Penn State, 315 East Health and Human Development, University Park, PA 16802, USA; Itk1@psu.edu}

Received 8 July 2004 Accepted 28 October 2004

\begin{abstract}
Background: The Barclay cigarette (Brown \& Williamson) was introduced in 1980 in the USA in the most expensive launch in history. In the USA and around the world, Barclay was later determined to have a grooved filter design that was compromised by human smokers in the normal act of smoking, but that was measured as ultra-low tar using the standard tar testing protocol.

Objectives: To evaluate whether Brown \& Williamson knew of the compensatability of Barclay during the design process and before it was released; to evaluate initial responses of competing tobacco companies to Barclay, before complaints were made to the Federal Trade Commission in 1981.

Methods: Internet databases of industry documents (Tobacco Documents Online, Legacy Tobacco Documents Library, Brown \& Williamson Litigation discovery website, Guildford and major company websites) were searched using key words, key dates, and targeted searches. Documents related specifically to the development, evaluation and release of the Barclay cigarette and related to the responses by competing tobacco companies were examined.

Results: Documents indicate the manufacturer was aware of Barclay design problems and was planning, before release, to respond to criticism. Competing companies quickly detected the filter groove stratagem and considered developing their own similar filter, but eventually backed off.

Conclusion: The design problems with Barclay were readily understood by cigarette manufacturers, including the maker of Barclay, before official governmental evaluations occurred. Testing involving measured exposures to human smokers may in the end be crucial to identifying problems with novel cigarette designs.
\end{abstract}

n 1980, Brown \& Williamson Tobacco Company (B\&W), an affiliate of the British-American Tobacco Company (BAT), was described by a leading business magazine as a "troubled" company that was "betting its future" on Barclay, ${ }^{1}$ its first ultra-low tar cigarette and object of the largest cigarette launch in history (\$150 million in 1980, equal to about $\$ 340$ million today). Remarkably, the $1 \mathrm{mg}$ tar King Size ( $3 \mathrm{mg}$ tar $100 \mathrm{~mm}$ ) cigarette broke sales records for a new cigarette within months of release. ${ }^{2}$

Ultimately, the original Barclay cigarette was found in the USA and around the world to circumvent official tar testing programmes. ${ }^{3}$ Much more so than other vented filter cigarettes, this ultra-low tar brand became a much higher tar cigarette in the hands and mouths of smokers than in the ports of official smoking machines. Because of its special grooved filter (fig 1), Barclay made it unavoidable for most smokers to compromise the filter ventilation system and compensate for reduced standard yields. Conventional ventilated filters allow diluting air to enter through vent holes that let smoke and air mix within the filter. Such a design allows behavioural blocking of air intake dilution holes. ${ }^{4}$ Barclay's grooves or channels were formed using a non-porous filter plug wrap that kept the diluting air separate from the rest of the filter. When these grooves became less effective, the entire ventilation system was compromised. On Barclay, air exit grooves as well as air intake holes could be blocked by smokers. ${ }^{4}$ In the course of normal smoking behaviours, the grooved dilution filter became compromised either by lips or fingers causing the air dilution channels to collapse or by lips blocking the exit of diluting air to the mouth. The filter ventilation system on Barclay functioned in a standard smoking machine test because the holding device on the machine used very little pressure compared to that arising from lips, fingers, and vigorous puffing.

It has been public knowledge that complaints from a competitor, the RJ Reynolds Tobacco Company (RJR), led to an investigation by the US Federal Trade Commission $(\text { FTC })^{25}$ and to open expressions of concern from other competitors. Once the FTC investigation began, Barclay was seen by most of the rest of the industry as a design that went too far toward being a compensatible product (copies of industry positions in the proceedings can be found here ${ }^{67}$ ). Industry behaviour before the FTC got involved provides historical insight into company principles and practices during the 1980s.

The public position of B\&W was expressed in December 1981 by the chairman of the board, Dr IW Hughes, in a videotaped statement played as part of a press conference: "Now I would like to state quite clearly that Brown \& Williamson adheres strictly to the highest ethical practices in its business. We developed and marketed BARCLAY honestly and we stand behind everything we say about the product to the consumer."

This report focuses on evidence from tobacco industry documents on the pre-history and early history of Barclay cigarettes in the USA. We explored documentary evidence of knowledge of the effects of the design before the FTC became involved in examining the product in 1981. Had the manufacturer been aware of Barclay's design problems before

Abbreviations: BAT, British American Tobacco; B\&W, Brown \& Williamson Tobacco Company; FTC, Federal Trade Commission; ISO, International Organization for Standardization; RJR, RJ Reynolds 


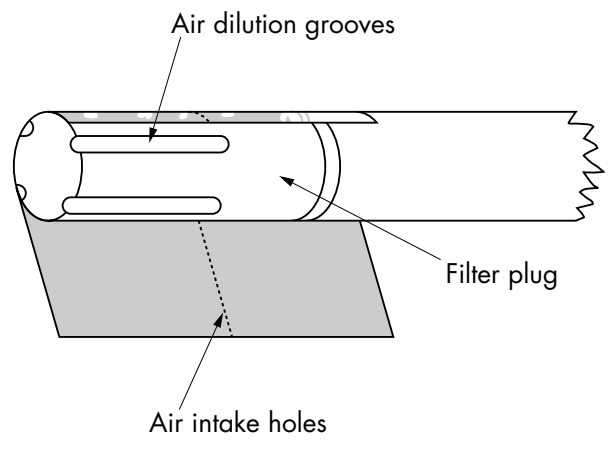

Figure 1 A diagram of the Barclay cigarette showing the air dilution grooves in the filter plug, and the air intake (ventilation) holes in the tipping paper. The filter is covered with a non-porous plug wrap before grooving. This non-porous plug wrap prevented diluting air from diverting to enter the filter plug and passing into the smoker's mouth, if the channels were blocked or compressed. Therefore Barclay was subject to air intake vents being blocked as well as air exit grooves being blocked. A common type of ventilated filter cigarette would not have grooved channels and would use porous plug wrap, so blocking air exit to the mouth would not be an issue.

selling the product? What did competitors know before the matter came before the FTC?

\section{DATA SOURCES AND SEARCH PROCEDURES}

The origin of the internal tobacco industry documents available for analysis is described by Katz and Lavack. ${ }^{9}$ The following databases were searched: Tobacco Documents Online (http://tobaccodocuments.org/), Legacy Tobacco Documents Library (http://legacy.library.ucsf.edu), the Brown \& Williamson Litigation Discovery website (http:// www.bwdocs.com/public.asp), and British Columbia's Guildford Depository collection (http://www.healthservices.gov.bc.ca/guildford/). We also searched all of the tobacco company websites directly.

Overlapping and integrated search strategies based on key words, key dates, and targeted for specific documents were used. Websites were searched for specific words singly and in combination, including but not limited to: "Barclay", "Actron", "compensation", "patent", "groove", "grooved", "grooves", "channel", "collapse", and "ultra low tar." As we read documents, more targeted searches were done using the names of projects (for example, "Omega", "Brand B") and key persons involved (for example, Johnson, Reynolds, Sanford, Gravely, Riehl, Alar, McCafferty, Silberstein).

Because chronology was important, we searched websites using key dates and date ranges. A document identified early in the search, "Development milestones of the Actron Filter", ${ }^{10}$ helped guide us. We also searched for very specific documents that we suspected or knew had existed (that is, those referenced in other documents or that might be more complete copies of documents we had already found). We used key words, names, specific dates and/or Bates numbers preceding or following numbers on the documents we had. For example, we searched for all B\&W documents including the name of Johnson (the Barclay inventor) from 1978 to 1981 and searching for " 244 " (a relevant project) and "notebook" produced laboratory notebooks.

These strategies were used by $2-6$ searchers, depending on the search, in multiple sites, to minimise chances of missing germane documents. Approximately 1200 documents of interest were downloaded and catalogued by date, document author, and Bates number. A master file with all documents included was constructed and searched before adding new documents to prevent duplication. Documents were read, studied, and discussed between at least two of the authors.
RESULTS

\section{Conception, development, and market release of} Barclay: 1978 to 1981

A period of nearly four years elapsed between the initial conception of the grooved filter in September 1978 and the final ruling by the FTC in June 1982. For a further account of developments following the ruling until March 1987, see Philip Morris. ${ }^{3}$ Our primary focus is on the period from 1978 until the time the FTC became involved in 1981 (table 1).

\section{B\&W documents show prior knowledge of the ease of} compensation issues with the grooved filter

There is converging evidence from the $\mathrm{B} \& \mathrm{~W}$ documents that indicate that $\mathrm{B} \& \mathrm{~W}$ scientists quickly identified the source of easy compensation (that is, smokers getting much higher smoke yields than indicated by standard testing), and notified company executives early on.

The inventor of the filter, RR Johnson, expressed interest in the issue of groove collapse and the possibility of having designed a compensatible cigarette on 11 December 1978 in a memo sent to five others with significant positions in B\&W (Dr RA Sanford, Director of Research and Development; TF Riehl, Division Head Products; ML Reynolds, Department Head; EF Litzinger, Section Leader; TG Strubel, Area Supervisor, Licensing and Liaison). He wrote, "We seem to have found a cigarette that shows low deliveries on machine smoking and much higher deliveries when people smoke it. One possible explanation is loss of filter ventilation by collapse of tipping into the grooves during hard puffing. ${ }^{.92}$

Remarkably, the official laboratory notebook entries during this same time period, from 22 September 1978, when the design conception was entered into his official laboratory notebook, ${ }^{12}$ through 15 December 1978, make no mention of this concern about groove collapse, even though the 12 December notebook entry contains the same numerical analytical results as reported in the memo of 11 December. As is standard for laboratory notebooks in industry in the USA (where priority of conception can be key to resolving patent disputes), each numbered notebook page is signed and dated by the author and witnessed, signed, and dated by two others. The failure to include the observation on "collapse" - even if speculative-in a scientific notebook

Table 1 Chronology of development and release of the Barclay cigarette in the USA

\begin{tabular}{|c|c|}
\hline September 1978 & $\begin{array}{l}\text { Conception of grooved filter by RR Johnson at } \\
\text { Brown \& Williamson Tobacco Company }{ }^{12}\end{array}$ \\
\hline $\begin{array}{l}\text { September } \\
1978-1980\end{array}$ & $\begin{array}{l}\text { Ongoing projects on grooved or fluted } \\
\text { filters }^{11} 9394\end{array}$ \\
\hline September 1980 & Test market release of Barclay cigarette ${ }^{95}$ \\
\hline 7 September 1980 & $\begin{array}{l}\text { Thomas Ahrensfeld, VP, General Counsel for } \\
\text { Philip Morris, phones Ernest Pepples, B\&W, to } \\
\text { discuss why Barclay produces a "higher level of } \\
\text { satisfaction to smokers than other } 1 \mathrm{mg} \text { tar } \\
\text { cigarettes" and that their "technical people had } \\
\text { developed a reason why they believe this is so" } \text { so }^{\prime \prime 96}\end{array}$ \\
\hline $\begin{array}{l}\text { September- } \\
\text { November } 1980\end{array}$ & $\begin{array}{l}\text { American Tobacco, Philip Morris, Lorillard, and } \\
\text { RJ Reynolds tobacco companies determined that } \\
\text { Barclay delivers more smoke to smokers than to } \\
\text { the standard smoking machine largely because } \\
\text { of groove compromise (table 2) }\end{array}$ \\
\hline $\begin{array}{l}\text { January } 1981- \\
\text { March } 1981\end{array}$ & $\begin{array}{l}\text { Nationwide release of Barclay cigarette, rising to } \\
\text { sales of } 1.2 \% \text { during the first quarter of } 1981^{84}\end{array}$ \\
\hline June 1981 & $\begin{array}{l}\text { FTC started informal investigation as a result of } \\
\text { complaint by RJR Tobacco Company }{ }^{96}\end{array}$ \\
\hline June 1982 & $\begin{array}{l}\text { FTC "concluded Barclay was inaccurately } \\
\text { measured by the FTC method and that the } \\
\text { cigarette actually delivered between three and } \\
\text { seven milligrams of tar when smoked by the } \\
\text { human being" }\end{array}$ \\
\hline
\end{tabular}


Table 2 Early evaluations of Barclay's functioning by competing companies

\begin{tabular}{|c|c|c|c|}
\hline Date & Company & Title & Quotations \\
\hline 9 September 1980 & LOR & Barclay & $\begin{array}{l}\text { "... visually Barclay }(1 \mathrm{mg}) 85 \text { appears to have } 2 \text { to } 3 \text { times as much smoke as the } \\
\text { Carlton }(1 \mathrm{mg}) 85^{\prime \prime 26}\end{array}$ \\
\hline 22 September 1980 & LOR & $\begin{array}{l}\text { Crude tar yields for Barclay } 84^{\prime} \text { 's at } \\
\text { different puff volumes }\end{array}$ & $\begin{array}{l}\text { "The Barclay filter generally collapses when smoked by humans which may result in } \\
\text { higher tar deliveries" }\end{array}$ \\
\hline 14 October 1980 & ATC & $\begin{array}{l}\text { Measurement of ventilation effects, } \\
\text { Barclay KS \& Carlton (83) soft pack }\end{array}$ & $\begin{array}{l}\text { "The slot design of the Barclay filter when smoked by machine apparently remains } \\
\text { intact and gives low tar delivery. However, when a smoker's lips close around the } \\
\text { filter and dampens it, the slots tend to close up, giving the smoker a much higher } \\
\text { delivery of smoke" }\end{array}$ \\
\hline 14 November 1980 & ATC & Barclay cigarettes & $\begin{array}{l}\text { "It becomes apparent that the lips of a smoker serve to restrict air flow through the } \\
\text { filter tip air dilution system of Barclay cigarettes by partially sealing off the four } \\
\text { grooves in the filter, thereby causing a larger proportion of the puff volume to be } \\
\text { drawn through the tobacco column"22 }\end{array}$ \\
\hline 10 September 1980 & RJR & Barclay cigarettes & $\begin{array}{l}\text { "...it is clear that the use of cigarette holders which apply more pressure on the } \\
\text { filter (Chemical Division holders) results in a substantially higher TPM delivery. It } \\
\text { appears that the pressure on the filter such as that a smoker applies during a puff } \\
\text { causes the tipping to collapse into the groove" } 48\end{array}$ \\
\hline 20 October 1980 & RJR & $\begin{array}{l}\text { Barclay evaluation under human } \\
\text { smoking conditions }\end{array}$ & $\begin{array}{l}\text { "It was found during initial testing that pressure applied to the filter caused the } \\
\text { tipping to collapse into the grooves, causing an increase in mouthend draft. } \\
\text { Additionally, it was shown that TPM deliveries rose dramatically when these } \\
\text { cigarettes were smoked with holders that applied the "squeezing" action on the } \\
\text { filter. It was speculated that when humans smoked the cigarettes, pressure from the } \\
\text { lips caused the same tipping collapse and thus produced smoking qualities very } \\
\text { different from other cigarettes with } \sim 1 \mathrm{mg} / \mathrm{cig} \text { FTC 'tar' deliveries... It is also } \\
\text { speculated that an even greater increase in TPM delivery might be obtained if the } \\
\text { smoker were allowed to manually handle the filter and further collapse the tipping } \\
\text { through finger pressure" }\end{array}$ \\
\hline 16 September 1980 & PM & Report on the Barclay cigarette & $\begin{array}{l}\text { "Product smokes differently in smoker's mouth than in dental dam of smoking } \\
\text { machine. Smoker's lips close channels (grooves) between tipping paper and filter } \\
\text { lowering dilution and resulting in higher tar delivery" }\end{array}$ \\
\hline 29 September 1980 & PM & Status of Barclay studies & $\begin{array}{l}\text { "This filter design results in some unusual delivery characteristics when smoked by } \\
\text { a human that do not occur during machine smoking... The dilution decrease to the } \\
\text { [human] smoker results in substantially higher tar delivery than would be the case of } \\
\text { a conventionally diluted all CA [cellulose acetate] filter... Subjective impressions by } \\
\text { flavor development have corroborated the higher tar estimates...filter process } \\
\text { development to either duplicate or simulate the Barclay effect is in progress" }\end{array}$ \\
\hline
\end{tabular}

violates standard laboratory practices. In the 15 December 1978 notebook entry, Johnson does provide data on the possibility that the strong taste was related to the very low pressure drop and changes in ventilation level with "more intense and bigger puffs" ${ }^{\prime 3}$ Though this entry is related to compensation, it is not in direct pursuit of the issue of "collapse of tipping into the grooves".

In late 1979, Johnson's annual performance review notes: "His "grooved filter" is corporately considered to be a technical breakthrough and our first innovative filter since Duolite. The fact that B\&W's next market entry will likely carry a "grooved" filter is largely due to Bob's diligence, persistence, enthusiasm and technical expertise." ${ }^{14}$ His "development plans" for 1980 are: "Further understanding of how/why 'grooved filter' affects smoke chemistry and smoke quality."

A strategic plan written five months before Barclay's test market indicates executive concern about extreme compensation. On 26 March 1980, clearly dated draft planning documents written by RA Sanford, then director of research and development, state: "Further, recognizing our concentration on grooved filter developments, we should develop a contingency plan for controlling the ease of compensation, if in the future, the product is excessively criticized. Here we might have to adjust the product to match the most flexible of our low tar competition." ${ }^{15}$ This document demonstrates high level knowledge-incorporated in planning documents that went to the board of directors and president of B\&W (see the slight revision in final planning documents in 1980). ${ }^{16}$

It was not until 25 April 1980 that Johnson's laboratory notebook referred again to the issue of groove collapse. ${ }^{13}$ The notebook page is entitled, "Invention disclosures grooved filter cigarettes", and describes a scotch tape reinforced grooved filter of which he notes: "Cigarette taste was not changed and tipping could not be collapsed into the grooves with the most rigorous puff I could take." ${ }^{13}$ This indicates that without reinforcement, puffing could collapse tipping into grooves as he had noted 14 months earlier. A related formal "Invention disclosure" memo dated 22 April 1980 indicates: "The purpose is to prevent smokers from distorting the grooves by taking particularly strong puffs." ${ }^{17}$ These notebook entries and disclosures set the stage for patent protection for variants of the grooved filter. We could not find evidence that this modified filter was used in Barclay.

\section{Competitors readily identified the grooved filter problem within weeks}

Each manufacturer maintains a system for assessing how competing products work as soon as they come on the market. It is routine to reverse engineer cigarettes as soon as they become available in test market. Within weeks all four major cigarette companies determined the basic design issues involved with Barclay (table 2). Evaluations by these companies included systematic taste tests, modified smoking machine analyses, and experimental studies of human smokers smoking Barclay with or without a holder as used in the FTC test. Two of the companies even used scanning electron microscopes to examine the filter-advanced and expensive technology for $1980 .^{18} 19$

To save space, we use two quotations from each manufacturer and provide references for additional documents related to their early evaluation of Barclay (American, ${ }^{20-25}$ Lorillard, ${ }^{26-35}$ Philip Morris, ${ }^{36-45} \mathrm{RJR}^{46-60}$ ) (table 2).

These excerpts from longer documents demonstrate that industry experts readily figured out the problem with groove compromise. Also note that the perception by smokers of stronger taste and more smoke than usual for a $1 \mathrm{mg}$ tar cigarette were key clues for their initial analyses. 
B\&W's response to the competitor's challenges $\mathrm{B} \& W$ documents speak repeatedly of "very strong", ${ }^{61}$ "surprisingly strong", ${ }^{62}$ "packs a fearful punch", ${ }^{63}$ and a "mouthful of smoke" "64 (rather than the mouthful of air to be expected from some comparisons to a $1 \mathrm{mg}$.tar, "80\%" ventilated cigarette), and yet, in contrast to other companies, we found nearly no speculation on what explained this powerful and surprising effect within the B\&W documents before other companies started to complain. The B\&W marketing research even showed that this new ultra-low tar cigarette would generally be too strong for other ultra-low tar smokers and would be more appealing to those smoking cigarettes in the low tar range. ${ }^{65}$ Before the other companies started to complain, one $\mathrm{B} \& \mathrm{~W}$ document raised a question about the cause of the "considerable and perhaps unexpected amount of taste", but the focus was on what might be special about the tobacco blend, not on the filter. ${ }^{66}$

$\mathrm{B} \& \mathrm{~W}$ did not admit to the groove collapse problem when competitors shared their assessments, but instead developed an alternative explanation for Barclay's good taste based on air and smoke swirling together in the mouth. In a series of memos in late 1980, B\&W scientists Don Silberstein and Drew McMurtrie described an elaborate aerodynamical theory, based loosely on "Coanda turbulence" (named for an early jet aircraft designer), stating in a "File note" "The grooved filter works in part because smoke and ventilating air mix in the smoker's mouth", and later, "When entering a person's mouth, the air exiting the grooves will pull surrounding air from the mouth and mix it with incoming tobacco smoke" ${ }^{\prime \prime}{ }^{68}$ This explanation became a key element of the defence of Barclay and appeared in videos and advertisements (fig 2). A marketing brochure from this time period describes "The inside story of the ACTRON filter" as follows: "But with the revolutionary ACTRON design, air and smoke each travel through completely separate channels- the air moving at 5 times the speed of the smoke. They swirl together for the first time as they enter and billow throughout the entire mouth. That's ACTRON's aerodynamic action, created by the strategic positioning of the air grooves. That's the "mouthful of smoke" you taste with Barclay." ${ }^{\prime 69}$

Before the FTC became involved, competing companies explored making their own version of the deceptive Barclay filter

An early reaction of Philip Morris, RJR, and American ${ }^{57} 5870$ was that they should each try to build their own version of

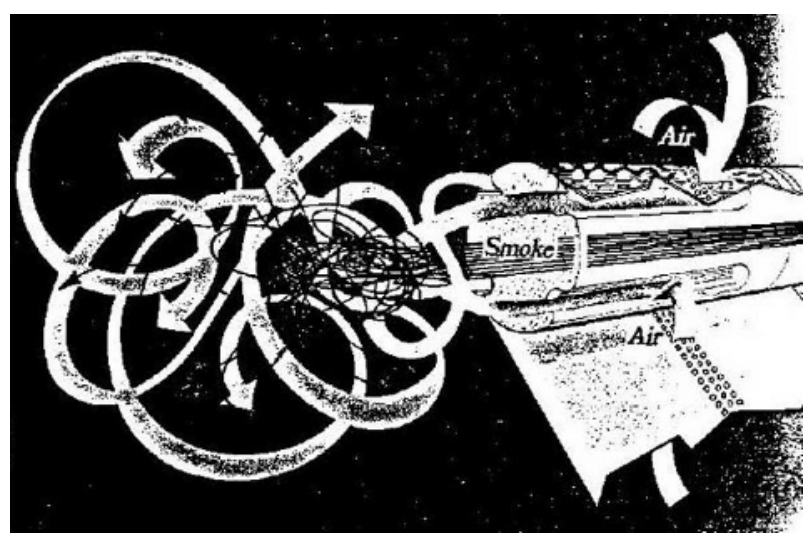

Figure 2 A Brown \& Williamson marketing brochure's depiction of the ACTRON filter and "swirl" explanation for Barclay's great taste. The diagram shows air entering through the special grooves in the cigarette and mixing together with smoke at the exit. This smoke and air mixture supposedly swirled and mixed together in the mouth, creating a "mouthful of smoke" taste. the grooved filter and speculation that they might already possess a patent that would protect such a design for them. ${ }^{47}$ Philip Morris in September began "Project Grow" to develop their own version of Barclay.$^{71}$ We could find no evidence that these products were ever marketed.

\section{DISCUSSION}

\section{B\&W had knowledge that the Barclay filter was a} defective design

The documents provide evidence that B\&W management and the Barclay inventor knew that Barclay provided the taste and smoke of a cigarette with a higher tar delivery because of how its filter performed when smoked by human smokers. Within weeks of discovery, the inventor of record proposed that the collapse of the filter was responsible for the remarkable taste from this type of cigarette. Planning documents indicate that $\mathrm{B} \& \mathrm{~W}$ was prepared to reduce the compensatory effect if criticism was too great. Other companies identified the filter problems of Barclay within weeks of its release on the market, by reverse engineering it themselves.

It is remarkable how consistently the B\&W and BAT documents provide no analysis of the groove collapse problem. Tobacco industry documents present important challenges for many reasons: a key document may be available but not found or a key document may not be found because it is unavailable. It is known that some documents from B\&W may have been moved to BAT in England. ${ }^{72}$ The BAT/ Guilford archive has been subject itself to criticism of the security and quality of the documents available there. ${ }^{73}$ Because of these limitations, we can make no judgment on whether documents are missing or if we were just unable to locate them.

\section{Why would a company knowingly market such a deceptive design?}

For all B\&W knew, they would have had the typical competitive advantage of a company coming first to market with an innovation. The marketing of Barclay could be seen as a calculated risk by a company in great need of a sales success. Also, the deception arising from the grooved filter was only greater than the deception involved with other ventilated filter designs: it was not the first example of a compensatible cigarette. ${ }^{4}$ Note that their "contingency plans" were essentially to reduce the compensation potential from Barclay and bring it more in line with the "flexibility" to be found in some competing brands. B\&W was merely the first company who gave an extremely compensatible cigarette a commercial try.

The "swirl" concept seems to have arisen as a strategy or diversion to draw attention away from collapse and deal with external criticism, rather than as part of the development of the grooved filter (for example, in Johnson's work). Years later (1985), WDE Irwin, a technician for BAT in England, was asked how a grooved filter could be made that would avoid criticism but also provide good taste. He concluded: "Finally for cigarettes, I believe it to be a self evident truth not only is there no smoke without fire, but also there is no kick without smoke." 75 He also noted that he never accepted the arguments about "swirl".

The "Barclay story" is particularly interesting in that RJR was moved to go to the FTC to try to deal with the matter, despite general reluctance to support regulation of tobacco products. Representatives of RJR expressed concern that the egregious problems with Barclay would "further impair the credibility of the Industry vis-à-vis Governments, the medical establishment, etc. I know this with certainty to be the case in West Germany, Great Britain, Canada and with less certainty for Switzerland." 59 There was concern that "the 
concept of "beating the FTC" would be legitimized" the FTC failed to act. While many of these same companies actively pursued the development of Barclay type designs, ${ }^{575870}$ they were concerned that the design went "too far" and would damage the reputation of the industry when "some anti-tobacco person will accuse Barclay of misleading the public and criticize the entire industry for its inaction" ${ }^{\prime 60}$

\section{The Barclay episode indicates fundamental limitations with standard machine testing in cigarette surveillance}

Surveillance is a cornerstone of public health. For decades the main product surveillance system for cigarettes has been the misleading FTC/International Organization for Standardization (ISO) standard smoking-machine test. ${ }^{79-83}$ This standard test helped cause the public health tragedy of the low tar cigarette.

A number of modifications of the official test protocols have been suggested over the years to try to provide a fairer basis for comparing brands. Some have suggested adding a "maximum yield" heavy smoking and blocked vent regimen. ${ }^{80}$ Others have proposed a simplified, two stage compensating test. $^{81}$ Still others have proposed flexible regimens derived from smoking topography measures in samples of smokers. ${ }^{82}$ We are not confident that any of these procedures would have detected the Barclay problem which would probably require modifying the smoking machine's cigarette holder to permit varying the pressure on the cigarette. A "maximum-yield" test would not have detected Barclay as a special problem. The issue with Barclay arose because of the ease and unavoidability of attaining a high yield. Testing involving measured exposures to human smokers may in the end be crucial to identifying problems with novel cigarette designs. ${ }^{83}$

\section{Brand related cigarette sales should be part of cigarette surveillance}

In the months before RJR discussed changing the cigarette holder in the FTC test, the documents indicate great concern about the dramatic increase in sales. ${ }^{84}$ In December 1980, Barclay was projected to pass the very significant $1 \%$ market share level in 1981; RJR projected that these sales would come in part from consumers of their brands and there was a recognised need to take "appropriate counteraction". ${ }^{84}$ In 1986 B\&W modified their filter to deal with the groove collapse problem, and the FTC permitted a $3 \mathrm{mg}$ tar rating. The market share of Barclay fell from a peak of over $1.2 \%$ in 1981 to less than $0.3 \%$ in 1990 (the most recent year for which we have data). ${ }^{85}$

Monitoring cigarette sales may help detect especially dangerous design innovations. From a public health standpoint, a brand that sells well stands to kill many customers; one that does not has a lower priority for public health attention. A brand selling or increasing in sales by $1 \%$ (or even $0.5 \%$ ) of the market could be targeted for specialised testing, including biomarkers in a sample of smokers. For poorer countries, enhanced testing of better selling products may be much more feasible than such testing of all products on the market. The World Health Organization Framework Convention on Tobacco Control provides guidance on other tobacco control measures overall that are needed. ${ }^{86}$

\section{Government and industry laboratories need not be the only source of cigarette testing}

We do support the creation of strong governmental regulation for cigarettes and tobacco products. In absence of such regulation, the current official, government sanctioned, industry approved testing procedures are difficult to change.

\section{What this paper adds}

The Barclay cigarette with a novel grooved filter was introduced in the USA in 1980 and was the subject of the most expensive launch in US history. This cigarette design ultimately became infamous around the world because of findings that it could not be properly analysed by official tar testing systems. The filter design became dysfunctional in smoker's mouth and hands, but not in the smoking machine.

We analysed documentary evidence on the manufacturer's awareness of this problem during development and on responses by competitors when Barclay was first sold and before governmental agencies became involved. We found evidence that: (1) the manufacturer was aware of the design problems and planned to respond to criticism before the product was released; and (2) four other companies readily detected the design problems and most considered developing their own deceptive filter. This episode provides insight into the relation between standard mainstream smoke yield and the design of cigarettes to satisfy consumers. The episode also argues for implementation of revised cigarette testing procedures in which cigarette sales trigger more detailed product testing, including exposure studies in human smokers.

Industry protection of the standard test may also be key to its continued dominance. ${ }^{87}$ Just as non-governmental groups can create, conduct, and report tests of automobile safety, consumer interested $^{88}$ or other organizations could create and perform their own cigarette tests, even including biomarkers in human smokers. ${ }^{81}{ }^{89}$ In the US, two popular magazines, Reader's Digest $^{90}$ and Consumer Reports ${ }^{91}$ first commissioned and reported machine smoked tar tests years before the government did. Perhaps further attention by such groups could lead to new tests that: (1) are better informed by what has been learned about the dangers of "low tar" cigarettes; and (2) would better inform consumers of dangers from cigarettes.

\section{ACKNOWLEDGEMENTS}

Thanks to Richard O'Connor for comments on earlier drafts, and to Tiffany Baird and Sima Seidman for their help in searching. Funded by a grant from the National Cancer Institute, 1-ROl CA095890-01Al "Analyzing Tobacco Documents on Cigarette Design."

SDS was also supported by NCI, POI CA68384 and CAl7613.

LTK was one of three expert consultants for the FTC on the Barclay case and JW was a lawyer for the FTC at the time. LTK, JW, and MEG have served as expert witnesses in litigation against the tobacco industry.

\section{Authors' affiliations}

L T Kozlowski, N A Dreschel, E B Weiss, Department of Biobehavioral Health, Pennsylvania State University, University Park, Pennsylvania, USA

S D Stellman, Department of Epidemiology, Columbia University, New York, USA

J Wilkenfeld, Campaign for Tobacco Free Kids, Washington DC, USA M E Goldberg, Department of Marketing, Pennsylvania State University

\section{REFERENCES}

1 Fortune Magazine. The $\$ 150$ million cigarette. 17 November 1980. Brown \& Williamson. Bates No. 657025331/5334. http://legacy.library.ucsf.edu/ $\mathrm{tid} /$ jav81d00.

2 Business Week. A flare-up over a cigarette filter. 13 July 1981. Brown \& Williamson. Bates No. 690152338. http://legacy.library.ucsf.edu/tid/ zqp93f00.

3 Philip Morris. Channel ventilated cigarettes-Barclay. 23 March 1987. Philip Morris. Bates No. 2501006188/6192. http://legacy.library.ucsf.edu/tid/ zlz19e00. 
4 Kozlowski LT, O'Connor RJ. Cigarette filter ventilation is a defective design because of misleading taste, bigger puffs, and blocked vents. Tobacco Control 2002; 11 (suppl I):i40-50.

5 Ramirez A. RJ Reynolds study of cigarette tar irks an industry rival [from the Wall Street Journal]. 6 May 1981. RJ Reynolds. Bates No. 502199946/9946. http://legacy.library.ucsf.edu/tid/ihv33a00.

6 Snyder WS. United States District Court for the District of Columbia, Federal Trade Commission, plaintiff, vs. Brown \& Williamson, defendant, exhibits volume 1. Undated. Brown \& Williamson. Bates No. 681603671/3905. http://legacy.library.ucsf.edu/tid/dcq01foO.

7 Snyder WS. United States District Court for the District of Columbia, Federal Trade Commission, plaintiff, vs. Brown \& Williamson, defendant, exhibits volume 2. 7 July 1983. American Tobacco. Bates No. 968065154/5382. http://legacy.library.ucsf.edu/tid/iiz24f00.

8 Hughes IW. Statement of Dr. I. W. Hughes. 15 December 1981. Brown \& Williamson. Bates No. 690152501/2502. http://legacy.library.ucsf.edu/ $\mathrm{tid} / \operatorname{lgp} 93 \mathrm{fOO}$

9 Katz SK, Lavack AM. Tobacco related ban promotions: insights from tobacco industry documents. Tobacco Control 2002;11(suppl I):i92-101.

10 British American Tobacco. Development milestones of the Actron filter. Undated. British American Tobacco Company. Bates No. 102222529. http://outside.cdc.gov/images4/00/02/56/36/doc00001.TIF (Accessed 26 May 2004)

11 Johnson RR. Cigarette with backflow filter ventilation. 11 December 1978. Brown \& Williamson. Bates No. 680596833/6834. http:// legacy.library.ucsf.edu/tid/vzs40f00.

12 Johnson RR. Brown \& Williamson research dept. 5 July 1977. Brown \& Williamson. Bates No. 621073318/3346. http://legacy.library.ucsf.edu/ $\mathrm{rid} / \mathrm{mj}$ iv90fo0.

13 Johnson RR. Technical research report book \#1332. 15 December 1978. Brown \& Williamson. Bates No. 620626185/6220. http:// legacy.library.ucsf.edu/tid/zon81d00.

14 Riehl TB. Performance appraisal, R Johnson project supervisor. 1 January 1979. Brown \& Williamson. Bates No. 470000101/0107. http:// tobaccodocuments.org/bw/1197361 1.html? (Accessed 26 May 2004).

15 Sanford RA. [Budget preview draft]. 26 March 1980. Brown \& Williamson. Bates No. 654073283/3297. http://legacy.library.ucsf.edu/tid/sbs99e00.

16 Brown \& Williamson. Reference material for 81 preview. 1980. Brown \& Williamson. Bates No. 670284578/4645. http://legacy.library.ucsf.edu/ $\mathrm{tid} / \mathrm{ldq} 50 \mathrm{fOO}$

17 Reynolds ML. Invention disclosure. Title: Grooved filter cigarette with narrow band tipping, 22 April 1980.Brown \& Williamson.Bates No.620397240.http://legacy.library.ucsf.edu/tid/aqn33f00.

18 Squires WC, Spence G. Electron microscopy and x-ray analysis. 30 June 1980. RJ Reynolds. Bates No. 502029046/9095. http:// legacy.library.ucsf.edu/tid/wpj29d00.

19 McGeady JC. SEM examination of the filter components of the Barclay $100 \mathrm{~mm}$ cigarettes. 5 December 1980. Lorillard. Bates No. 80000539/0547. http://legacy.library.ucsf.edu/tid/feb54c00.

20 American Tobacco. Barclay type cigarettes. 22 September 1980. American Tobacco. Bates No. 950819435/9443. http://legacy.library.ucsf.edu/tid/ vxc90a00.

21 American Tobacco. Measurement of ventilation effects. 14 October 1980. American Tobacco. Bates No. 946019123/9129. http:// legacy.library.ucsf.edu/tid/bfy $15 f 00$.

22 Sprinkle RS III. Barclay cigarettes. 14 November 1980. American Tobacco. Bates No. 990273993/4001. http://legacy.library.ucsf.edu/tid/frz05f00.

23 Sprinkle RS III. Barclay kings and 100s cigarettes manufactured by Brown \& Williamson. 17 November 1980. American Tobacco. Bates No. 946019137/9142. http://legacy.library.ucsf.edu/tid/ffy15fo0.

24 Leake PH. Barclay cigarettes. 29 December 1980. American Tobacco. Bates No. 950705079/5080. http://legacy.library.ucsf.edu/tid/rwo4la00.

25 Petrencs JG Jr. [Memo from J. G. Petrencs to E. H. Bonnabeau]. 3 February 1981. American Tobacco. Bates No. 950053335. http:// legacy.library.ucsf.edu/tid/bfb31a00.

26 Hudson AB. Barclay. 9 September 1980. Lorillard. Bates No. 00302520/ 2521. http://legacy.library.ucsf.edu/tid/drt6le00.

27 Ihrig AM. Crude tar yields for Barclay 84 's at different puff volumes. 22 September 1980. Lorillard. Bates No. 81081300. http:// tobaccodocuments.org/lor/81081300.html? (Accessed 26 May 2004).

28 Shoffner RA. UV analysis of tar levels on Barclay cigarette butts. 22 September 1980. Lorillard. Bates No. 00400879. http:// legacy.library.ucsf.edu/tid/cct61e00.

29 E-Chung W. The collapse of the filter of Barclay cigarettes. 26 September 1980. Lorillard. Bates No. 86026556/6558. http://legacy.library.ucsf.edu/ $\mathrm{tid} / \mathrm{kj}$ b98c00.

30 Hudson AB. Barclay 85. 8 October 1980. Lorillard. Bates No. 80006314. http://legacy.library.ucsf.edu/tid/lku31 e00.

31 Norman V. Information on the Barclay cigarette. 8 October 1980. Lorillard. 87398223/8226. http://legacy.library.ucsf.edu/tid/gif1 le00.

32 Hurst RW. Analysis of Barclay filters by FTIR and GC. 10 October 1980 Lorillard. Bates No. 00370069/0072. http://legacy.library.ucsf.edu/tid/ odk68c00.

33 Norman V, Ihrig AM. Smoke yield of Barclay at different puff volumes. 16 October 1980. Lorillard. Bates No. 87398211/8216. http:// legacy.library.ucsf.edu/tid/ejf1 le00.

34 Norman V. Visit to American Health Foundation. 18 November 1980. Lorillard. Bates No. 01391373/1375. http://legacy.library.ucsf.edu/tid/ dyz99d00.
35 Norman V. A filter conception separating smoke and diluting air flow paths. 21 November 1980. Lorillard. Bates No. 87632613/2615. http:// legacy.library.ucsf.edu/tid/koj98c00.

36 Meyer LF. Report on the Barclay cigarette. 15 September 1980. Philip Morris. Bates No. 2028681570/1578. http://legacy.library.ucsf.edu/tid/ kyo $25 \mathrm{e} 00$.

37 Philip Morris. PDT meet. 16 September 1980. Philip Morris. Bates No. 1003713999/4001. http://legacy.library.ucsf.edu/tid/pby97e00.

38 Philip Morris. Market activity, Richmond meeting. 9 September 1980. Philip Morris. 2021648336/8342. http://legacy.library.ucsf.edu/tid/cii44e00.

39 Goodale $\Pi$. New products meeting. 16 September 1980. Philip Morris. Bates No. 1003637364/7366. http://legacy.library.ucsf.edu/tid/ivu54e00.

40 Houck WG. Status of Barclay studies. 29 September 1980. Bates No. 1000785893. http://legacy.library.ucsf.edu/tid/nts54e00.

41 Meyer LF. Development project summary grooved filter program (Barclay). 20 September 1980. Philip Morris. Bates No. 1000784608/4609. http:// legacy.library.ucsf.edu/tid/lvm28e00.

42 Goodman B. Smoking studies. September 1980. Philip Morris. Bates No. 2022179484/9485. http://tobaccodocuments.org/pm/20221794849485.html? (Accessed 26 May 2004)

43 Houck WG. New cigarette products. October 1980. Philip Morris. Bates No. 2022179535/9536. http://legacy.library.ucsf.edu/tid/rnc71 foO.

44 Goodman B. Smoke studies. October 1980. Philip Morris. Bates No. 2022179555/9556. http://tobaccodocuments.org/pm/20221795559556. html? (Accessed 26 May 2004).

45 Bonhomme J. An evaluation of the Barclay ad and product. 14 November 1980. Philip Morris. Bates No. 950374808/4827. http:// legacy.library.ucsf.edu/tid/txh0la00.

46 Johnson DP. First analysis of Barclay cigarettes. 8 September 1980. R. J. Reynolds. Bates No. 507330408/0408. http://legacy.library.ucsf.edu/tid/ Ird34d00.

47 Rodgman A. Research weekly highlights. 10 September 1980. R. J. Reynolds Bates No. 500544205/4207. http://legacy.library.ucsf.edu/tid/kdd79d00.

48 Townsend DE. Barclay cigarettes. 10 September 1980. R. J. Reynolds. Bates No. 512326020/6021. http://legacy.library.ucsf.edu/tid/adq51c00.

49 Threatt HC Jr. Monthly report, technology development. 16 September 1980. R. J. Reynolds. Bates No. 503031782/1789. http://legacy.library.ucsf.edu/ $\mathrm{tid} / \mathrm{hzp} 68 \mathrm{~d} 00$.

50 Squires WC. Structure of filter on Barclay cigarette. 17 September 1980. R. J. Reynolds. Bates No. 510698843/8844. http://legacy.library.ucsf.edu/tid/ erp93a00.

51 Lewis L. Analytical report, research department, R.J. Reynolds Tobacco Company [Barclay 85, 100]. 19 September 1980. R. J. Reynolds. Bates No. 504456417/6421. http://legacy.library.ucsf.edu/tid/cdt33a00

52 R. J. Reynolds. Cigarette analysis report. 22 September 1980. R. J. Reynolds. Bates No. 504165156/5158. http://legacy.library.ucsf.edu/tid/beu33a00

53 Rodgman A. Weekly highlights. 8 October 1980. R. J. Reynolds. Bates No. 500928174/8176. http://legacy.library.ucsf.edu/tid/bfp59d00.

54 Stowe ME. Status Report - Fundamental R\&D. 15 October 1980. R. J. Reynolds. Bates No. 500928185/8186. http://legacy.library.ucsf.edu/tid/ dfp59d00.

55 Norman AB, Townsend DE. Barclay evaluation under human smoking conditions. 20 October 1980. R. J. Reynolds. Bates No. $511308378 / 8382$ http://legacy.library.ucsf.edu/tid/fwb53d00.

56 Duffy DJ. Special report on Barclay test market performance. 21 November 1980. R. J. Reynolds. Bates No. 503771103/1135 http:// tobaccodocuments.org/rir/503771 103-1135.html? (Accessed 26 May 2004).

57 Goss JW. Barclay performance report. 26 November 1980. R. J. Reynolds. Bates No. 503771099/1102. http://legacy.library.ucsf.edu/tid/uqf85d00.

58 Piehl DH. Barclay filter. 18 December 1980. RJ Reynolds. Bates No. 508044925/4925. http://legacy.library.ucsf.edu/tid/eeu04d00.

59 Colby FG. Barclay cigarettes. 26 February 1981. RJ Reynolds. Bates No. 502444347/4347. http://legacy.library.ucsf.edu/tid/ley09d00.

60 R. J. Reynolds. Call to Ernie Pepples. 1981. R. J. Reynolds. Bates No. 503740271/0272. http://legacy.library.ucsf.edu/tid/nsj85d00.

61 Johnson RR. Low Tar Slim Cigarettes with Conventional and Grooved Filters. 28 March 1979. Brown \& Williamson. Bates No. 650325960/5966. http:// tobaccodocuments.org/bw/70287.html?.

62 Georgia Bender Research. Tar wars: A qualitative look at introductory activity of Winston Ultras and Merit Ultra Lights. March 1981. Brown \& Williamson. Bates No: 666056167/6213, http://legacy.library.ucsf.edu/tid/zxc83f00.

63 Reynolds ML. Gemini status as of 2/14/80. 14 February 1980. Brown \& Williamson. Bates No. 500000046/0050. http://legacy.library.ucsf.edu/ $\mathrm{tid} / \mathrm{pbv} 10 \mathrm{fOO}$

64 Tighe PJ. 1mg/3mg/Technology project. 14 January 1980. Brown \& Williamson. Bates No. 663004443/4446. http://legacy.library.ucsf.edu/ $\mathrm{tid} / \mathrm{cnm} 83 \mathrm{foO}$.

65 Hawkins, McCain \& Blumenthal. Omega Review. 3 May 1980. Brown \& Williamson. Bates No. 660026719/6734. http://legacy.library.ucsf.edu/ $\mathrm{tid} / \mathrm{irs} 89 \mathrm{e} 00$.

66 Brown \& Williamson. Major marketing decision recommendation. 29 July 1980. Brown \& Williamson. Bates No. 660036591. http:// legacy.library.ucsf.edu/tid/hfs89e00.

67 Silberstein DA. Investigation into why the grooved filter works. 23 October 1980. Brown \& Williamson. Bates No. 690150653/0655. http:// tobaccodocuments.org/bw/347432.html? (Accessed 26 May 2004).

68 Porenski HS. A physical interpretation of Barclay airflow. 12 November 1980. Brown \& Williamson. Bates No. 650522636. http:// tobaccodocuments.org/bw/54331.html? (Accessed 26 May 2004). 
69 Brown \& Williamson. The inside story of the ACTRON filter. 1982. Philip Morris. Bates No. 2025046285/6286. http://legacy.library.ucsf.edu/tid/ fiq25e00.

70 Seligman RB. Project GROW. 23 October 1980. Philip Morris. Bates No. 2021644244. http://legacy.library.ucsf.edu/tid/kdh44e00.

71 Houck WG. Project Grow development project summary. 3 November 1980 Philip Morris. Bates No. 1000784920. http://tobaccodocuments.org/pm/ 1000784920. html.

72 Wells JK. Document retention. 17 January 1985. Brown \& Williamson. Bates No. 680530888/0890. http://tobaccodocuments.org/bw/12281012.html.

73 Muggli EM, LeGresley EM, Hurt RD. Big tobacco is watching: British American Tobacco's surveillance and information concealment at the Guildford depository. Lancet 2004;363:1812-19.

74 Collin J, Lee K, Gilmore AB. Unlocking the corporate documents of British American Tobacco: an invaluable global resources needs radically improved access. Lancet 2004;363:1746-7.

75 Irwin WDE. Redesign Barclay without Actron. 25 January 1985. Brown \& Williamson. Bates No. 102969202. http://outside.cdc.gov/images4/00/ 02/55/89/doc00001.TIF (Accessed 4 April 2004).

76 Reynolds JH. Possible consequences of failure of the FTC to act against the Barclay cigarette filter and its mimics. 4 March 1982. RJ Reynolds. Bates No. 503670658/0659. http://legacy.library.ucsf.edu/tid/onq44a00.

77 Kozlowski LT, Rickert W, Robinson J, Grunberg NE. Have tar and nicotine yields of cigarettes changed? Science 1980;209:1550-1.

78 National Cancer Institute. The FTC cigarette test method for determining tar, nicotine, and carbon monoxide yields of US cigarettes: report of the $\mathrm{NCl}$ Expert Committee. Bethesda, Maryland: National Institutes of Health, National Cancer Institute 1996, (NIH Publication No 96-4028.).

79 World Health Organization. Advancing knowledge on regulating tobacco products. Geneva: WHO, 2001.

80 Heath Canada. Determination of "tar," nicotine and carbon monoxide in mainstream tobacco smoke. Heath Canada. December 1999. Hp, //www.hcsc.gc.ca/hecs-sesc/tobacco/pdf/T-115e4.PDF (Accessed July 2004).

81 Kozlowski, LT, O'Connor RJ. Official cigarette tar tests are misleading: use a two-stage, compensating test. Lancet 2000;355:2159-61.

82 National Tobacco Monitoring, Research and Evaluation Workshop, held November 4-6, 2002, Bethesda, MD, sponsored by NCl, CDC, ACS and Legacy Foundation.

83 Benowitz NL, Hall SH, Herning RI, et al. Smokers of low-yield cigarettes do not consume less nicotine. N Engl J Med 1983;309:139-42.
84 Mawell JC. The Maxwell Report: first quarter 1981 sales estimates for the cigarette industry. 27 April 1981. Philip Morris. Bates No. 2060415249/ 5258. http://legacy.library.ucsf.edu/tid/ich67d00

85 Walker L. Barclay: strategic planning session. 10 August 1990. Brown \& Williamson. Bates No. 604003865/3896. http://legacy.library.ucsf.edu/ $\mathrm{tid} / \mathrm{ozi} 33 \mathrm{fOO}$

86 WHO link to FCTC documents. http://www. who.int/tobacco/framework/en.

87 Bialous SA, Yach D. Whose standard is it, anyway? How the tobacco industry determines the International Organization for Standardization (ISO) standards for tobacco and tobacco products. Tobacco Control 2001;10:96-104.

88 Brecher R, Brecher E, Herzog A, et al. ed. The Consumer's Union report on smoking and public interest. Mount Vernon, New York: Consumers Union, 1963.

89 Gray N, Kozlowski LT. More on the regulation of tobacco smoke: how we got here and where next. Ann Oncol 2003;14:353-7.

90 Miller LM, Monahan J. Wanted-and available-filter-tips that really filter [Reader's Digest report]. August 1957. Lorillard. Bates No. 03760669/0676. http://legacy.library.ucsf.edu/tid/wml13c00.

91 Consumer Reports. Tars and nicotine in cigarettes, report \#1 in CU's continuing tests. October 1957. Lorillard. Bates No. 88044016/4017 http://legacy.library.ucsf.edu/tid/svl13c00.

92 Johnson RR. Cigarette filter including grooves in the filter plug. 31 January 1979. Brown \& Williamson. Bates No. 680596816/6819. http:// legacy.library.ucsf.edu/tid/bxg33fo0.

93 Johnson RR. Cigarette with backflow ventilation system. 4 December 1978. Brown \& Williamson. Bates No. 650510400. http://legacy.library.ucsf.edu/ $\mathrm{tid} / \mathrm{rze} 00 \mathrm{fOO}$

94 Johnson RR. Cigarette filter including grooves in the filter plug: status report. 23 January 1979. Brown \& Williamson. Bates No. 510003131/3134. http://legacy.library.ucsf.edu/tid/ril10f00.

95 Brown \& Williamson. McCann prepares Barclay introduction (from AdWeek) 15 September 1980. Brown \& Williamson. Bates No. 690152226. http:// legacy.library.ucsf.edu/tid/nop93f00.

96 Brown \& Williamson. The controversy: a capsule chronology. September 1980. Brown \& Williamson. Bates No. 690140657/0665. http:// legacy.library.ucsf.edu/tid/ago81c00

97 Federal Trade Commission. Barclay cigarettes "tar," nicotine and carbon monoxide higher than measured by current FTC tests. 25 June 1982. Brown \& Williamson. Bates No. 690151498/1499. http://legacy.library.ucsf.edu/ $\mathrm{tid} / \operatorname{ltp} 93 f 00$ 